ТЕБЕНКО Вячеслав Александрович, Петрозаводский государственный университет, ООО «Сталь Сервис»,

г. Петрозаводск, Россия stal12h18n@mail.ru

\section{К ВОПРОСУ О СОЗДАНИИ КАРЕЛЬСКОЙ АВТОНОМИИ 1920-1923 гг.} тономии в Карелии в период образования РСФСР и СССР. Цель статьи показать, что возникновение Карельской автономии - это процесс связанный больше с внутренней политикой большевиков, гражданской войной, а не близостью Финляндии и деятельности финновкоммунистов. Исходя из цели, автор видит свою задачу в первую очередь указать на весьма схожие причины и механизмы, по которым возникали другие национальнотерриториальные автономии в различных частях РСФСР в начале 20- X гr. (Татарская, Чувашская, Марийская, Коми автономия), будь то автономные области или автономные республики. В рамках статьи проиллюстрированы основные исторические события 1918-1925 гг., связанные с созданием указанных автономий. Подобное описание и анализ необходимы чтобы подчеркнуть определенную универсальность в национально-государственном строительстве РСФСР. Также следует сказать, что политика большевиков в отношении регионов и национальностей в статье рассматривается вместе с событиями гражданской войны и противостоянием населения большевикам после официального установления советской власти на тех или иных территориях. В ходе исследования были использованы индуктивный, сравнительноисторический, проблемно-хронологический и логический методы. Автор сравнивая, процесс создания автономий ещё во время гражданской войны, указывает на множе ство совпадений при создании автономий в РСФСР в очень непохожих регионах бывшей Российской империи. Всё это позволяет говорить о создании Карельской автономии как результате внутренних в первую очередь внутренних изменений и реформ в Советской России Соседство с Финляндией определяло в данном случае определяло внешнюю форму, а не суть этого процесса.

Vyacheslav A. TEBENKO, Petrozavodsk State University, STAL SERVICE LTD,

Petrozavodsk, Russia stal12h18n@mail.ru

\title{
TO THE QUESTION ABOUT CREATING THE KARELIAN AUTONOMY IN 1920-1923
}

This article examines the causes of autonomy in Karelia during the formation of the RSFSR and the USSR. The article aims to reflect the fact that the emergence of Karelian autonomy is a process associated more with the domestic policy of the Bolsheviks and the civil war, not close location of Finland or the activity of Finnish communists. Based on the purpose, the author sees his task to point out the very similar reasons and mechanisms that gave rise to other national and territorial autonomy in various parts of the USSR in the early 20-ies (Tatarstan, Chuvash, Mari, Komi) no matter if it was autonomous regions or autonomous republics. The author demonstrates the main historical events of 1918-1925, which are connected with the formation of the mentioned autonomous. The necessity of the detailed description is to emphasize the certain universality of the formation of the RSFSR. It should be noted that the author scrutinize the Bolshevik policy together with the events of civil war and indigenous people opposition of the official the establishment of the Soviet regime at that regions. There were used methods as follows: inductive, comparative-historical, problem-chronological, logical in the scientific work. By comparing the process of creating autonomies in the RSFSR during the civil war at very different regions of the former Russian empire, the author reflects a lot of points to match that allow talking about the creation of autonomy in Karelia as a result of local changes in the RSFSR, and Finnish neighborhood determined its external form.

Ключевые слова: Карелия, автономия, трудовая комму- Keywords: Karelia, autonomy, labor commune, на, РСФСР, национальная политика, военный коммунизм, RSFSR, national politic, military communism, civil гражданская война, Марийская AO, Коми, Чувашия, Баш- war, Mari AD, Komi, Chuvashia, Bachkiria, Tatarstan кирия, Татарстан.

В советской историографии главной причиной создания Карельской автономии в начале 20-х гг. прошлого века в виде Карельской Трудовой Коммуны, а потом Карельской Автономной Республики указывалось то, что «советское правительство, неуклонно руководствуясь ленинской национальной политикой, горячо поддерживало стремление карельского народа к самоопределению в составе Советской России» [1, с. 136]. Здесь следует выделить работы В.И. Машезерского, М.И. Шумилова.

В постсоветской историографии значительное внимание в создании Карельской автономии стало уделяться внешнеполитическому фактору - близости Финляндии и деятельности «красных» фриннов. Необходимо отметить работу А.А. Левкоева (1995 г.) [2, с. 24-50]. В ней исследователь делает вывод, что деятельность «красных» финнов во главе с Гюллингом и взаимоотношения Советской России с Финляндией стали главными условиями для создания карельской автономии, сначала в виде коммуны, а в дальнейшем - автономной республики.

Схожая точка зрения была высказана Ю.М. Килиным в его монографии «Карелия в политике советского государства 1921-1940 гг.». Килин считал, что причиной создания КТК было стремление стабилизировать внутриполитическую ситуацию в Карелии и лишить Финляндию предлогов для постановки «карельского» вопроса на мирных переговорах (1920 г.). Создание автономной республики было связано с воздействием финляндской дипломатии и новыми подходами к решению национальных проблем, выработанными центральными властями [3, с. 8487]. В «официальной», если можно так сказать, истории Карелии послесоветского периода во- 
просы создания КТК и КАССР связываются в первую очередь с внешней политикой СССР в отношении Финляндии [4, с. 446]. Необходимо обратить внимание на монографию А.И. Бутвило «Карельская Трудовая Коммуна». Автор пишет, что решение карельского вопроса требовало таких мер, которые бы укладывались в рамки национального строительства и нейтрализации главного требования финнов - самоопределения карел, с учетом имеющегося уже опыта национального строительства у башкир, татар и приграничного положения Карелии [5, с. 30]. Однако исследователь почти не рассматривает опыт национального строительства во внутренней политике в отношении Карелии.

Фактору внутриполитической обстановки в деле создания карельской автономии не уделено должного внимания. В настоящей статье мы попробуем проследить роль внутриполитического фактора в становлении карельской и других национальных автономий, показать его значение. В основе нашего исследования будет сравнительно-исторический метод. Мы будем говорить о нескольких национальных автономиях, созданных большевиками в начале 20-х гг., выявляя общие и характерные черты в указанный хронологический период.

В первую очередь нужно сказать о том, что создания КТК, КАССР совпадают как по характеру, так и по времени с аналогичными процессами в других национальных областях РСФСР; разумеется, здесь необходимы соответствующие примеры, которые мы приведем. Вовторых, вопросы национальной политики, территориального устройства принципиально решались высшим советским руководством. В этом сможет убедиться читатель, увидев, как порой четко совпадают многие процессы и решения как местных, так и центральных властей применимо к разным территориям. Ленин и Сталин еще до революции подробно разбирали национальные вопросы в своих работах, причем их выводы и предложения - это не идеологические штампы, а вполне взвешенные решения национального вопроса в Российской империи [6].

Прежде всего, мы определим национальные автономии для дальнейшего анализа. Уместным будет выбрать создание автономий Чувашской, Башкирской, Татарской и Марийской. Почему именно эти национальные территории? Во-первых, эти автономии создавались примерно в одно и то же время. Все они входили в РСФСР, а не в союзные республики. Во-вторых, они не имели внешних границ (а сравнивать мы будем с приграничной Карелией). В-третьих, удаленность от центра, особенно «национальных» районов этих автономий, периферийность, определенная хозяйственная и политическая замкнутость. В-четвертых, это малонаселенность некоторых территорий (Чувашия, Марийская автономия), что объединяет их с Карелией, и, напротив, большие по численности Татарстан, Башкирия, с довольно мощным национальным и религиозным движением вовсе не похожи на Карелию. Также следует обратить внимание на статусы автономий. Высшей формой автономии была республика, которая являлась как бы «государством», имеющим свои государственные атрибуты; автономные области были по статусу ниже и не имели своих ЦИКов, наркоматов, конституций; трудовые коммуны были близки по статусу к автономным областям. Следует отметить, что в РСФСР было всего две коммуны, затем преобразованные в автономные республики: в Карелии, близкой к Финляндии (до 1923 г.), и Трудовая коммуна немцев Поволжья (до 1924 г.). Вероятно, идеи мировой революции, интернационализма сыграли роль в подобном наименовании.

Начнем с революционного процесса и создания автономии в Карелии. Гражданская война с участием совершенно разных внутренних и внешних сил привела к тому, что различные территории Карелии в разное время контролировались разными политическими силами. Это Временное карельское правительство (север), финны (Поросозерская и Ребольская волости на западе) [7, с. 64], Олонецкая директория (юго-запад), Олонецкая добровольческая армия.

Весной 1919 г. для большевиков складывается критическая ситуация в Карелии: белое движение получает мощную поддержку со стороны Финляндии. Под угрозой белофиннов самый большой город и центр революционного движения - Петрозаводск, но с конца июня 1919 г. Красная армия переходит в контрнаступление, занимая южные районы Карелии. А с начала 1920 г. идет наступление Красной Армии на северные территории таким образом, что 26 февраля 1920 г. был занят Медвежьегорск, а весной было начато наступление на Ухту, центр Временного карельского правительства, 18 мая 1920 г. Ухта занята Красной армией. Собственно, зима-весна 1920 г. - это переход большей части Карелии под контроль Красной Армии. И уже в апреле-мае идет подготовка к созданию карельской автономии. Следует заметить, что Ленин встречался и с большевиками от Олонецкой партийной организации, потом с деятелями финляндской коммунистической партии Э. Гюллингом и Ю. Сиролой по вопросу создания карельской автономии. 3 июня 1920 г. оргбюро Олонецкого уездного совета обратилось с воззванием к трудящимся Карелии принять участие в съезде карельского народа, съезд проходил в начале июля. А 8 июня 1920 г. 8 декретом ВЦИК была создана Карельская трудовая коммуна (КТК) в составе РСФСР. В состав Революционного комитета высшего органа власти вошли Гюллинг, Мяки (финские коммунисты) и Куджиев (местный большевик). 
1-3 июля состоялся всекарельский съезд, который должен был «решить» судьбу Карелии. На съезде были поставлены вопросы: должно ли карельское население остаться в составе РСФСР, создать самостоятельные государство или карельские волости должны войти в состав Финляндии? Почти 90\% населения Олонецкой губернии высказались в пользу РСФСР. Советская власть в определенной степени показала мировой общественности «легитимное и демократичное» решение «карельского» вопроса.

Бутвило и Килин говорят о том, что одной из причин столь быстрого создания КТК было стремление нейтрализовать претензии финнов по вопросу самоопределения для карел. Вполне вероятно, так оно и было, однако в дальнейшем мы увидим, что в других регионах подобные решения принимались с не меньшей быстротой. Кроме того, говоря о роли Финляндии, нельзя забывать, что май 1920 г. - это разгар сепаратизма на Аландских островах, чьи лидеры очень надеялись на Швецию. Это тоже было серьезной внешнеполитической проблемой, но уже для Финляндии, впоследствии урегулированной через Лигу Наций [8, с. 144-146].

В августе 1920 г. декретом ВЦИК и Совнаркома за подписями Ленина и Калинина были определены границы КТК, население которой составило 144,393 тыс. человек, из них 60\% составляли карелы, 37\% - русские [9, с. 140]. В Карельскую трудовую коммуну вошли территории Олонецкой и Архангельской губерний. Первоначально планировалось, что центром КТК будет Медвежьегорск или Кемь, однако выбор был сделан в пользу «русского» Петрозаводска [10, с. 42]. По вопросу территорий, вошедших в состав КТК, были дискуссии между различными группами и ведомствами, но для нас важно отметить, что, несмотря на относительно раздельное проживание карел и русских и возможности создания карельской автономии, пусть на меньшей территории, но этнически более монолитной, КТК все же получилась смешанной в национальном отношении. Произошло это, как указывает Бутвило, соглашаясь с Машезерским, вследствие того, что возобладал «классовый» подход и вместе с русскими в состав области вошел отряд рабочих, сыгравших ведущую роль в революционном движении. Мы тоже будем солидарны с историками. Однако, возможно, что «русские» районы вошли не только благодаря «красным» финнам с их «революционным» подходом, но больше по указаниям центральных властей, ибо в других автономиях вхождение «русских» районов происходило точно так же. Таким образом, можно сказать, что завершился начальный этап становления Карельской автономии в форме трудовой коммуны. Вместе с тем произошло завершение относительно крупных военных действий, гражданская война заканчивалась. Что происходит в дальнейшем? 1921 г. - крайне неудачный для всей Советской России: неурожай и продовольственный кризис приводят к восстаниям во многих областях РСФСР. В Карелии восстания начались в октябре 1921 г. Как пишет К.И. Соколов-Страхов, время для вооруженных выступлений, подготовленных Финляндией, было выбрано в тот период, когда в полной мере обнаружатся все неудачные результаты посева и будет сбор продналога [11, с. 44]. Автор подробно разбирает политическую и моральную подготовку финляндского населения к оказанию помощи восставшим карелам, говорит о фринских офицерах и добровольцах-организаторах вооруженных отрядов. В частности, о финском «Восточно-Карельском» комитете, организации, занимавшейся сбором помощи восставшим, лесопромышленном объединении «Гутгейтц», фринансировавшем добровольцев [12, с. 45-47]. Вооруженное восстание проходило под национальными лозунгами и под общим руководством Карельского временного правительства. Разумеется, восставшие были связаны с финской эмиграцией, в нем участвовали фринны-добровольцы. Однако основными участниками восстания были жители Карелии, а причиной вооруженных выступлений стали голод и катастрофическое положение местного населения, об чем пишут Килин и Левкоев [13, с. 56, с. 41]. Килин, ссылаясь на архивные данные, говорит, что карельские чекисты называли причинами местные фракторы, а не влияние Финляндии. Об этом же пишет и Соколов-Страхов, а именно то, что местное население не оказывало сопротивления финским отрядам, так как те обещали в случае успеха снизить налоги, удешевить продовольствие, а большим плюсом для агитации были тяжелые продовольственные затруднения местного крестьянства, пережившего голод в 1920 г. [14, с. 48] (упоминает он об этом лишь настолько, насколько позволяла цензура в конце 20-x).

Помимо разверстки и денежных налогов, тяжелым бременем на крестьян ложились трудовая и гужевая повинности, которые выполнялись в любое время года. Общий убыток от всех крестьянских платежей и трудгужповинности достиг в 1920/21 г. не менее 1/4 условно-чистого дохода. Разумеется, как это бывает в любом восстании, в ходе событий появились политические лозунги и мотивы. Уже в ноябре 1921 г. в Ухте собрался съезд представителей карел, провозгласивший цель борьбы - независимость Карелии [15, с. 146]. Тем не менее в феврале 1922 советские войска взяли Ухту и восстание сошло на нет. Далее в Карелии проходят различные внутриполитические события, борьба за власть между местными коммунистами и «красными» финнами. Не вдаваясь в политические хитросплетения, нужно отметить один мо- 
мент, весьма важный для нашего рассуждения, что в состав КТК из Олонецкой губернии был передан Повенецкий уезд и часть Пудожского вместе с городом Пудож. Если Повенецкий уезд в начале 20-х гг. был карельским по этническому составу, то территории Пудожского уезда всегда были «русскими», и тем не менее они переданы в КТК. В апреле 1923 проходит XII съезде РКП (б), где среди прочего большое внимание уделяется вопросам национального строительства. Разумеется, значение XII съезда - это отдельная тема, единственное, о чем следует сказать, что на съезде национальный вопрос решался в пользу национальных окраин, по крайней мере декларативно и тактически.

За съездом последовали перемены и для карельской автономии. 25 июля 1923 г. КТК была преобразована в Автономную Карельскую Советскую Социалистическую Республику. В 1924 г. территория и население республики увеличивается за счет Прионежья, в основном вепсов; ранее эти территории были в составе Олонецкой губернии, потом Петроградской. Формируются довоенные границы Карельской АССР и завершается процесс территориального оформления автономии, в которой теперь проживает уже 221,6 тыс. человек: из них 42,7\% карел и вепсов и 55,7\% русских [16, с. 181]. То есть чуть больше чем за три года Карельская автономия в этническом и территориальном отношении из карельской превращается в конгломерат карельского и русскоязычного населения. Можно сделать вывод, что территория автономии, созданная как национальная, постоянно увеличивалась за счет «русских» районов уже в начале своего образования. Повышался статус автономии, увеличивалась территория, но доля "титульного» этноса сокращалась, хотя очевидно были возможности создать более компактную, но этнически более однородную автономию, передавая отдельные уезды в состав «русских» губерний [17]. Что касается экономической стороны дела, то в 1922 г., после того, как в споре между большевиками Олонецкой губернии и «красными» фриннами центральные власти поддержали Гюллинга, в Карелию в широком объеме стали поступать средства на восстановление лесозаготовок. А в 1923 г., после создания автономной республики, Гюллингу удалось добиться существенных бюджетных привилегий и прав, что позволило быстро поднять экономический и культурный уровень в Карелии [18, с. 58-59]. С самого начала создания КТК идет активный процесс привлечения «националов» в руководство автономией, несмотря порой даже на то, что «русские руководители» имели больше заслуг.

В отношении языкового вопроса центральное правительство также не чинило препятствий. Отметим решение ЦК РКП(б), которое предписывало КТК ввести наравне с русским языком и фринский [19, с. 144]. Поощряется использование карельского языка в устной форме, так как карельский не имел письменности. В дальнейшем финскому языку в районах, населенных карелами, предоставляется статус официального в администрации и образовании наряду с русским. Естественно, бюджетные привилегии, развитие языка были даны центром не столько из гуманитарных, сколько из сугубо практических соображений. Исследователи сходятся во мнении, что создание автономной области в виде коммуны, а затем повышение статуса было связано с требованиями экономической самостоятельности и повышения статуса территории, что отвечало внешнеполитическим целям СССР по решению «карельского вопроса», в том числе с его постановкой в Лиге Наций [20, с. 446], как сказано в «Истории Карелии». По мнению Килина, «автономная область была преобразована в автономную республику с воздействием финляндской дипломатии, так и с новыми подходами к решению национальных проблем, выработанных центральными властями» [21, с. 86]. Крупнейший исследователь карело-финских отношений И.Р. Такала полагает иначе: создание карельской автономии, с ее точки зрения, во многом заслуга Гюллинга и его сторонников - деятелей Коммунистической партии Финляндии [22, c. 144].

Теперь перенесем внимание читателя в регионы Поволжья и Урала, по многим параметрам отличающиеся от Карелии. Национальные вопросы, пути их решения от культурной автономии вплоть до сепаратизма в таких регионах Урала, Поволжья как Башкирия и Татарстан переплетались с религиозным фрактором. Причем этот круг проблем существовал еще задолго до Февральской революции. В период гражданской войны здесь происходило достаточно много драматичных событий, попробуем остановиться на более значимых для нашего рассуждения.

29 июля 1917 г. проходил Второй Всероссийский мусульманский съезд, на котором был принят документ «Основы национально-культурной автономии мусульман внутренней России», где появилось официальное название этнической общности «тюрко-татары» [23]. Национальное собрание, или Миллет меджлисе, провозглашалось высшим законодательным органом. Уже 6 января 1918 г. Национальное собрание провозгласило создание штата Идель-Урал [24], татары и башкиры, наряду с чувашами и марийцами - всего более 7 млн человек - должны были составить основное население штата, включающего всю Уфимскую, Казанскую губернии, западную часть Оренбургской губернии, некоторые уезды Самарской, Вятской, Пермской, Симбирской губерний [24]. В Башкирии было несколько иное видение автономии. В декабре 1917 г. 
III Всебашкирский Учредительный курултай принял положение «Об автономном управлении Башкурдистана», согласно которому автономия состояла из девяти кантонов. В то же время штат Идель-Урал, в перспективе объединявший огромное количество мусульман, не устраивал также большевиков и был явным препятствием в борьбе за власть. Для них это было бы потерей всего Поволжья.

События развивались довольно быстро, намеченное на 28 февраля 1918 г. провозглашение штата в Казани, было пресечено Казанским Советом рабочих, солдатских и крестьянских депутатов. Потом были разогнаны мусульмано-тюркские органы: Военный Совет в Казани и Национальное управление в Уфе. Военный совет просуществовал не более месяца в татарской части Казани в виде «Забулачной республики» и был подавлен вооруженными отрядами большевиков в конце марта 1918 г. Можно сказать, что вопрос о неподконтрольной большевикам национальной автономии был решен. Однако национальное движение в Поволжье не перестало существовать, напротив, только получило дополнительные импульсы, и игнорировать его и не взаимодействовать с ним большевики себе позволить не могли. Весной 1918 г. ими был выдвинут проект национальной государственности татар и башкир в форме Татаро-Башкирской ССР. 23 марта 1918 г. в газете «Правда» публикуется «Положение о Татаро-Башкирской Советской республике». В Москве не желали никакого объединения мусульман снизу и каких-то самостоятельных тюрко-мусульманских «республик». Татаро-башкирская республика, возможно, по замыслу большевиков, была бы контролируемым национальным образованием, где можно было постоянно играть на противоречиях между двумя национальными элитами, объединенными в одну автономию. Летом 1918 г. разгорается Гражданская война, в августе Народная армия Комуча заняла Казань, для большевиков складывалось критическое положение. В этих условиях вопрос о том, кого поддержит мусульманское население, главным образом башкиры и татары, становился принципиальным.

В Башкирии тем временем власть перешла в руки Башкирского шуро (главный орган власти), образовавшегося в ходе революции и гражданской войны в 1918 г. Шуро пыталось установить контакты с советской властью, инициаторами этих контактов выступали лидеры национального движения. Это совпало с боями между красными и белыми за территории Башкортостана. 31 декабря 1918 г. Красная Армия вошла в Уфу. На повестке дня для советской власти была борьба с Колчаком и Дутовым, которая, возможно, без поддержки башкир могла быть безуспешной. Тем более, что башкирские части, как и лидеры башкир, могли выступить как против большевиков, так и против Колчака. В январе - начале февраля 1919 г. идут переговоры между правительством Башкирии, которое в обмен на лояльность требует признания автономии Башкирии. В результате этих переговоров правительство Башкирии 8 февраля объявило, что с 18 февраля 1919 г. территория Малой Башкирии [25] становится составной частью РСФСР [26, с. 149-150]. Довольно скоро, уже 18 февраля 1919 г., последовал приказ № 5 о переходе башкирского корпуса на сторону Красной Армии и определявший расположение двух башкирских дивизий против войск белых, кроме того была объявлена амнистия всем, кто содержался под стражей за поддержку большевизма [27]. 20 марта 1919 г. было принято решение центрального Советского правительства и правительства Башкирии создать Башкирскую Автономную Советскую Социалистическую республику, 23 марта в «Известиях ВЦИК» прошло сообщение о создании БАССР [28]. Центром БАССР стал Стерлитамак, который в то время находился еще на территории Уфимской губернии [29]. Значительную роль в этих событиях сыграли «националы», например Валидов (Заки Валиди), который в дальнейшем оказался лишним во взаимоотношениях между БАШССР и Москвой, так как стремился к подлинной автономии башкир.

В состав БАШССР вошли территории Пермской, Оренбургской, Уфимской и Самарской губерний. Общая территория составила 78,4 тыс. кв. км. с населением 1,249 млн человек [30]. Следует отметить, что точных данных об этническом составе БАШССР нет, так как перепись 1920 г. проходила в сложных условиях. Хотя к концу июля 1919 г. с территории Уфимской губернии были выбиты армии Колчака, обстановка оставалась неспокойной. В новообразованной Малой Башкирии происходило жесткое противостояние коммунистических структур и башкирских властей, а в феврале 1920 г. в Закамье вспыхнуло мощное крестьянское восстание «Черного орла» (в литературе его называют еще «вилочным» восстанием), охватившее Уфимский, Мензелинский, Белебеевский, Бирский уезды Уфимской губернии, а также затронувшее Самарскую и Казанскую губернии. В Уфимском уезде мятеж непосредственно охватил северные и западные волости, отряды крестьян подходили на несколько десятков верст к Уфе (в городе вводилось военное положение). Одной из главных причин мятежа стало выкачивание из края запасов продовольствия, по сути неприкрытый грабеж деревни. Нужно отметить также тот факт, что происходила борьба за власть теперь уже между вчерашними сторонниками большевиков из числа создателей башкирской автономии и теми, кто видел свое политическое будущее уже в 
советском «проекте». К середине марта 1920 восстание было подавлено частями Туркестанского фронта и Приуральского сектора войск вооруженной охраны республики [31, с. 116].

Важно отметить, что с завершением активной фразы гражданской войны и после подавления национального восстания начинают происходить территориальные изменения. Мензелинский уезд БАШССР, один из центров восстания «Черного орла», где проживало значительное число башкир, был передан Татарской АССР декретом от 27 мая 1920 г. [32]. А в БАШССР из состава Уфимской губернии был включен г. Стерлитамак с шестнадцатью волостями. Необходимо отметить, что по переписи 1897 г. Стерлитамакский уезд был на $33 \%$ русскоязычным по населению. Такие территориальные изменения происходят на начальном этапе создания башкирской автономии в рамках РСФСР.

1921 г. не только для Башкирии, но и для всей страны ознаменовался народными выступлениями; на территории Башкирии появились отряды Охранюка-Черкесского, к ним присоединилась ушедшие в подполье отряды башкир Амантаева и Магасумова. Разумеется, восстание нашло многочисленных сторонников среди местного населения. Однако в это время большевики уже имели военные и политические ресурсы для эфффективной борьбы с такими стихийными выступлениями и восстание вскоре было подавлено. Спустя год после восстания происходит событие, которое мы не можем не отметить. 14 июня 1922 г. ВЦИК принял декрет «О расширении границ Автономной Башкирской Социалистической Советской Республики». Создавалась "Большая Башкирия» [33], Уфимская губерния упразднялась, и три ее уезда Уфимский, Бирский и Белебеевский - передавались Башкирской республике. Столица БАШССР переносилась из г. Стерлитамака в г. Уфу [34, с. 110]. Надо заметить, что именно летом 1922 г. была упразднена Олонецкая губерния, а Петрозаводск стал столицей Карельской трудовой коммуны. На первый взгляд - типичное изменение административных границ в процессе построения социалистических республик. Но на что следует обратить внимание: Бирский уезд по переписи 1920 г. по этническому составу только менее чем на четверть был башкирским [35, с. 122]. Далее Белебеевский уезд, где, согласно переписи, башкирское население составляло чуть более половины, причем было значительное количество русского населения [36, с. 13-64]. Что касается Златоусского уезда, то в БАШССР были переданы восемь волостей из 23, которые никак нельзя назвать башкирскими по этническому составу. Только в одной из них, Янабаевской, башкир было 71,2\% - 4377 чел., в Новопетропавлоской башкир уже 17,4\%, или 716 человек, а по остальным волостям значительно меньше [37]. Очевидно, что такие привилегии на деле вели к сокращению башкирской автономии. Понимали это и современники. Так, газета «Власть труда» 5 июля 1922 г. писала, что, несмотря на численное превосходство других народов «Большой Башкирии» над башкирами, «власть Советской России этот переход [Уфимской губернии к Башкирской республике] санкционировала». В итоге по этническому составу, согласно переписи 1926 г., собственно башкир в БАШССР стало менее четверти всего населения 23,4\% [38]. Стоит сказать, что и естественные географические препятствия (большие реки, горные хребты), если смотреть на карту БАШССР, не определяли такие вот административные границы башкирской автономии. Присоединенные «русские» районы могли быть частью других областей, но почему-то стали частью национальной автономии башкир.

Что касается экономической политики, то в условиях перехода к НЭПу наметились положительные сдвиги как в сельском хозяйстве, так и в промышленности. В частности, нужно сказать, что для развития сельского хозяйства было создано общество «Башсельхозкредит». Был организован завоз лошадей, устроено несколько конных заводов, что, конечно, имело большое значение для крестьян Башкирии. Для руководства хозяйственной жизнью власти организовали Башкирское губернское экономическое совещание, а также промышленные объединения «Башпром», «Башлес», «Башторг», восстановлена деятельность Белорецкого металлургического завода и т.д. Согласно конституции Башкирской АССР у нее, как и других автономных республик, был свой бюджет.

В отношении языка Конституция Башкирии закрепила решения различных съездов и волеизъявлений башкирского народа. За гражданами республики признавалось право свободного пользования родным языком на съездах, в суде, управлении и общественной жизни. Официальными языками в БАШССР признавались башкирский и русский языки, указывалось на необходимость судебным органам республики учитывать бытовые особенности башкирского трудового народа [38, с. 139]. Завершая разговор о Башкирии, нужно обратить внимание читателя на то, что существенное увеличение территорий автономии происходит за год до известного XII съезда РКП(б), а сам процесс создания автономии и привлечения «националов» очень сильно сопряжен с фазами гражданской войны. В какой-то степени «автономизация» выглядит как попытка центральных властей решить проблемы вооруженного противостояния, вступая в союз с «националами», с другой стороны, эта автономия в общем-то с каждым шагом большевиков становиться все менее «башкирской» как по территориям, так и по этническому составу. 
В соседнем Татарстане события складывались схожим образом, но с некоторым «опозданием», возможно, события в Башкирии выступали катализатором создания Татарской автономии. Проблема для центральных властей, о чем мы уже говорили, заключалась в том, что игнорировать национальное движение в Поволжье было невозможно. Как и в случае с Башкирией, требовалось привлечь на свою сторону национальных лидеров татар, лояльно настроенных к большевикам. Одними из самых ярких лидеров татарского национального движения были М.Х. Султан-Галиев и В.В. Вахитов; вместе они обороняли Казань от белогвардейцев и фрормировали мусульманские части Красной Армии. После гибели Вахитова в августе 1918 г., СултанГалиев возглавил Центральную военную коллегию мусульман. Это была реальная не только политическая, но и военная сила. Именно Султан-Галиев вел переговоры с Валидовым о переходе башкир на сторону советской власти. Харизматичный, образованный, имеющий огромное влияние и авторитет в мусульманском мире, вероятно Султан-Галиев должен был стать лидером мусульман Поволжья [39]. Он выдвинул проект создания Татаро-Башкирской советской республики. Однако в декабре 1919 г. состоялось заседание Политбюро ЦК РКП (б), на котором было принято решение таковой республики не создавать.

Логика большевиков вполне понятна: более монолитные и лучше организованные мусульмане во главе с такими лидерами, как Валидов, Султан-Галиев - независимыми, принципиальными, обладающими военными силами, преданными им, а не советской власти - большевикам были не нужны [40]. Создание национальной автономии стало происходить «управляемо». В начале 1920 г. после решения Политбюро ЦК РКП (б) от 26 января 1920 г. была создана межведомственная комиссия для подготовки проекта декрета об образовании Татарской республики. В комиссию были включены представители Наркомнаца, НКВД и Центрального бюро коммунистических организаций народов Востока при ЦК РКП (б). Комиссия должна была разработать вопрос о территориальных границах будущей Татарской республики. В марте 1920 г. состоялась II Казанская губернская конференция коммунистов-татар. В работе конференции обсуждались вопросы о национально-государственном строительстве и отмечалась необходимость скорейшей организации Татарской республики.

В начале мая 1920 г. работа по подготовке проекта декрета о создании Татарской Автономной Советской Социалистической Республики в основном завершилась. В частности, по настоянию представителя центра предусматривалось включение в республику лишь Мензелинского уезда Уфимской губернии. В согласованном варианте проект предусматривал образование автономной Республики Татарстан в составе 12 уездов бывшей Казанской губернии, исключая 5 уездов с чувашским и марийским населением. Дополнительно в состав республики входили из Самарской губернии - 26 волостей Бугульминского уезда, из Вятской губернии - 7 волостей Малмыжского уезда, из Симбирской губернии - 3 волости Симбирского уезда, 10 волостей Буинского уезда. Территория Республики составляла 67,8 тыс. км, с населением - 2,892 млн человек, в том числе татары - 51\%, русские - 39,2\%. Эта территория оказалась значительно меньше фактической национальной территории татарского народа на его исторической родине - в Волго-Урале. Более половины татарского населения и соответственно татарские земли были оставлены в составе соседних русских губерний. В таком виде проект Положения об образовании Автономной Республики Татарстан был утвержден Декретом ВЦИК и СНК 27 мая 1920 г., декрет был подписан председателем ВЦИК М.И. Калининым и председателем СНК В.И. Лениным. Декрет закрепил основы государственно-правового статуса республики [41, с. 67].

Следует обратить внимание на то, что создание Татарской АССР может быть случайно, но совпало с пиком разногласий в Башкирии между самостоятельным Валидовым и сторонниками центра по вопросам автономии. В итоге в мае 1920 г. Валидов вышел в отставку. Татарская автономия, включившая в себя далеко не все этнически татарские территории, в дальнейшем, ни в 1922, ни в 1923 г., не получила дополнительных территорий. Вероятно, с регионом, вдвое большим Башкирии по населению, с вековыми традициями обособленности, если не сепаратизма и мусульманской идеологией большевики решили не экспериментировать.

Если говорить об экономическом развитии республики, то развитие автономии очень удачно совпало с НЭПом. Был создан Татсовнархоз, который восстанавливал старые предприятия, объединял промышленность в тресты. В частности, были восстановлены крупнейший в России мыловаренный и свечной завод братьев Крестовниковых (тогда он стал заводом имени М. Вахитова) и Алафузовская льнопрядильная фабрика (стала им. Ленина). Кроме того, Татсовнархоз передал в частные руки 46 промышленных предприятий [42]. В сельском хозяйстве, благодаря Декрету о земле, повышался процент середняков, возникали трудовые артели и коллективные хозяйства.

В рамках национально-языковой политики в конце 1922 г. ТатЦИК утвердил инструкцию «O реализации татарского языка». Происходило последовательное внедрение татарского языка в делопроизводство. В дальнейшем, в 1923-1925 гг., последовал ряд мероприятий и постанов- 
лений, определивших направления, методы и формы работы в этой области. Большую роль в реализации татарского языка сыграли Постановление Всесоюзного ЦИК от 14 апреля 1924 г. «О мерах к переводу делопроизводства государственных органов в национальных областях и республиках на местные языки» и постановление Татарского ЦИК «О реализации татарского языка в государственных учреждениях и предприятиях ТАССР». Также происходила «коренизация» государственного аппарата [43].

Если резюмировать создание татарской автономии, то можно сказать, что национальное движение татар было вовремя взято под контроль большевиками с помощью лидеров из числа лояльно настроенных к ним «националов». Вновь созданная автономия получилась советской и социалистической, причем значительно меньшей, если бы границы проходили по районам расселения татар. Проект Штата Идель-Урал, Волжско-Уральской республики, который бы объединял народы Поволжья и Урала, разумеется с перспективой усиления центра этих территорий, объединения мусульманского и тюркского мира был успешно остановлен. Автономия татар в итоге получилась русско-татарской, уже по переписи 1926 г. численность татар составляла 1,2634 млн чел. (48,7\%), а русских 1,1188 млн чел. (43,1\%), при том что численность всех татар в СССР составляла 2,9163 млн. Естественно необходимо делать коррекцию, но очевидно, что большая часть проживала в сопредельных с Татарской АССР областях и республиках [44].

Теперь рассмотрим менее населенный регион Поволжья - Чувашию. В мае 1917 г. в Казани состоялся I съезд малых народностей Поволжья, высказавшийся за национальное самоопределение, правда, лишь культурное, не политическое. І Общечувашский национальный съезд (июнь 1917 г.) работавший в Симбирске, также высказался за культурную автономию. Для действий было создано «Чувашское национальное общество», находившиеся под влиянием эсеров. Левым эсерам принадлежала руководящая роль в борьбе за национальное самоопределение и после октября 1917 г. В марте 1918 г. при Казанском губернском Совете появляется Комиссариат по чувашским делам. А в мае 1918 г. чувашский отдел создается при Наркомнаце РСФСР. Его возглавил левый эсер Д.С. Эльмень. Появление этого отдела означало признание высшими органами государственной власти проблемы национального вопроса у чувашей.

Вопрос о форме самоопределения чувашского народа активно начал обсуждаться с начала 1918 г. в связи с планами создания Средневолжского и Южноуральского штата, позже его предполагалось назвать Волго-Камским штатом. В его состав предполагалось включить территорию, населенную чувашами. Потом идея штата трансформировалась в проект Татарско-Башкирской республики, большую часть которой должны были составлять мусульмане: татары, башкиры, а другие народы Среднего Поволжья и Приуралья - мари, удмурты, чуваши оставались бы в меньшинстве. Позицию чувашских организаций по этому вопросу выработал I Общечувашский рабоче-крестьянский съезд. Он высказался против вхождения чувашей в состав планируемой республики, так как они оказались бы в ней национальным меньшинством (12\%). Обобщая свою позицию по национальному вопросу, съезд констатировал, что по уровню политического развития и этногеографическому положению чуваши еще не готовы создать самостоятельное, независимое от других народов государственное образование в составе РСФСР. Но в августе 1918 г. в связи с тем, что Казань взяли чехословаки и войска Комуча, под предводительством уже правых эсеров активизировалось «Чувашское национальное общество», организация с претензией на выражение интересов всего чувашского народа. Однако 10 сентября в Казань вновь вошла Красная Армия, и вскоре «Чувашское национальное общество» прекратило свое существование. Тот же вопрос национального устройства и самоопределения был на повестке дня, и что важно для нас, был он использован как большевиками, так и белыми, конечно не в той степени, как в Башкирии и Татарстане.

Работники восстановленных в Казани советских учреждений объявили о создании Коммунистического комитета, в члены которого записались Д.С. Эльмень, Л.М. Лукин, В.А. Алексеев, А.П. Прокопьев (Милли) и другие чувашские активисты. Вероятно, эти деятели, имеющие связи и определенное влияние среди национальной интеллигенции, были выбраны большевиками и сыграли свою роль в становлении чувашской автономии, даже не будучи абсолютными сторонниками большевиков (Эльмень был левым эсером). Уже в конце гражданской войны, в феврале 1920 г., I Всероссийский съезд чувашских коммунистов одобрил разработанный Чувашским отделом Наркомнаца документ - «Положение об организации Чувашской трудовой коммуны» (разработано по примеру Трудовой коммуны немцев Поволжья и Карельской трудовой коммуны) [45, с. 375].

Вопрос чувашской автономии решился вслед за образованием Татарской АССР, Декрет СНК и ВЦИК РСФСР «Об Автономной Чувашской области» был подписан 24 июня 1920 г. В состав Чувашской Автономной области вошли целиком три уезда - Чебоксарский, Цивильский, Ядринский, ряд волостей Козьмодемьянского уезда (бывшей Казанской губернии), а также Кур- 
мышского и Буинского уездов Симбирской губернии. Площадь области составляла 115 тыс. кв. км., численность населения - более 805 тыс. человек. Коренное население в пределах области составляло 85\% [46, с. 28]. Это был очень высокий показатель «титульной» нации для автономии. Возможно, так произошло вследствие отсутствия мощного национального движения и вооруженных формирований из национальных сил, как это было в Башкирии или Татарстане. Определенное противоречие: очень высокий процент «титульного» этноса, а статус автономии - область, то есть ниже, чем республика.

Зимой 1920-1921 г. вследствие политики продразверстки, военного коммунизма и особого рвения нижних «эшелонов» власти в Чувашии, как и по всей стране, произошел ряд выступлений против советской власти. Как пишет чувашский исследователь Ратникова, реально вооруженных выступлений было немного: в Акульевской волости, наступление восставших на г. Цивильск, в Чувашско-Сороминской волости. В ходе подавления вооруженных выступлений, только со стороны большевиков было более 100 погибших [47, с. 29-32]. Естественно, такие выступления без лидеров, подготовки, малочисленности участников скоро были подавлены властями и говорить о каком-то влиянии на развитие автономии не приходится.

Что касается развития автономии, в языковой политике были определенные изменения в пользу чувашского языка. В январе 1922 г. постановлением исполкома области чувашский язык был введен «в качестве государственного и обязательного» во всех государственных учреждениях. Это было началом политики «реализации чувашского языка» как второго государственного, политики реального двуязычия. В экономическом плане центральные власти шли навстречу местным руководителям, значительно возрос бюджет автономии. Исследователь В.В. Орлов пишет, что быстрые темпы роста бюджета автономии в 22,4 раза (!) объяснялись не только изначально низким уровнем бюджета, но большими государственными дотациями и увеличением неналоговых поступлений. Уровень государственных дотаций составлял от 2/3 до 3/4 всего бюджета, а лесной доход обеспечивал до $33 \%$ всех неналоговых поступлений в бюджет [48].

В 1922-1924 г. происходило обсуждение дальнейшего развития автономии Чувашии. Незначительные изменения административных границ: территориальные обмены между Чувашской АО и Татарской АССР (1921г.), передача территорий во вновь образованную Марийскую AO (1923 г.). Местные власти разрабатывали увеличение автономии в 2,8 раза за счет соседних губерний и автономий - так называемый проект «Большая Чувашия» [49]. Проект так и остался проектом, но 21 апреля 1925 г. была провозглашена Чувашская АССР, и после ряда согласований и изменений 15 июня 1925 г. Президиум ВЦИК принял постановление «О государственном устройстве Чувашской АССР». Чувашский и русский были объявлены равноправными языками на территории Чувашской АССР. 20 июля 1925 г. Президиум ВЦИК принял решение о расширении границ Чувашской АССР. Из состава Чувашской АССР в Марийскую АО было передано 7 сельсоветов, а в Чувашскую АССР вошли 3 волости Алатырского уезда. В итоге территория Чувашской автономии увеличилась, выросла численность населения, но доля чувашей сократилась на 10\% [50]. Что интересно, в Алатырском уезде по переписи 1897 г. проживало 158,188 тыс. человек, из них $73,4 \%$ - русские, $26,7 \%$ - мордва [51]. То есть чувашского населения в принципе не было, но тем не менее русский город Алатырь был включен в состав Чувашской АССР. С точки зрения административных границ Алатырский уезд вполне мог войти в Симбирскую губернию или Средневолжский край, то есть в более близкие этнически территориальные образования.

В целом можно отметить, что создание Чувашской автономии происходит во многом не как самостоятельное явление, но как часть «управляемого» процесса автономизации Поволжья, с привлечением «националов»-революционеров. Можно наблюдать аналогичную с Карельской АССР картину: завершение гражданской войны, создание автономии в виде области, с преобладающей титульной нацией, затем территориально-административные изменения, расширение автономии, повышение статуса, уровня экономики, увеличение численности населения, но в то же время сокращение доли титульного этноса.

Завершая разговор о Поволжье, рассмотрим создание Марийской автономной области. В начале революционных событий 1917 г. среди марийцев в первую очередь обсуждались идеи культурной автономии. На V Всероссийском съезде марийского народа, состоявшемся в июле 1917 г. в городе Бирске Уфимской губернии, вопросы территориально-политической автономии не ставились, речь шла о языке и культуре. Первые организации марийцев появились еще в марте 1917 г. среди восточных марийцев [52] (уㅣ, Бирск), летом 1917 - в Царевококшайском, Уржумском уездах. В основном эти организации выступали за ликвидацию культурной отсталости марийского народа, открытие национальных школ, ведение преподавания в них на родном языке. Они были одной из форм национального общественно-политического движения марийской интеллигенции. Возник Центральный Союз мари (Марий ушем) в Казани. В декабре 1918 г. Центральный Союз мари был запрещен большевикам, обществам мари было предписано стать 
культурно-просветительскими кружками. Взамен них были организованы марийские отделы и секции при уездных партийных и советских органах. Опять можно констатировать тот факт, что большевики не могли игнорировать национальное движение, но там, где оно было сильным, с ним взаимодействовали, «раскалывали», а когда была возможность, просто запрещали, если это не грозило вылиться в серьезные выступления. Одним из членов Центрального союза мари был С.А. Черняков. В 1919 г. Черняков начинает работать в Центральном отделе мари при Наркомнаце, уже будучи коммунистом [53]. Очевидно, большевики берут национальное движение под свой контроль. В ходе гражданской войны, после изгнания Колчака с Урала, в 1919 г. была образована Башкирская Республика, которая по договору вошла в состав РСФСР, но земли восточных мари не были выделены и не получили какого-либо особого статуса, а просто стали частью Башкирской АССР.

Однако по завершению гражданской войны, с февраля 1920 г. среди марийцев началось обсуждение вопроса об образовании Марийской автономной области. В волостях, населенных марийцами, проводились собрания, на которых принимались решения о необходимости образования области. В Казани состоялось Всероссийское совещание активных работников мари, где основным был этот же вопрос. Летом на Всероссийской конференции коммунистов-мари в Казани обсуждался уже конкретный план организации автономии, были намечены руководители органов власти и управления по государственной и партийной линии.

В большинстве волостей с марийским населением прошли сельские сходы, волостные совещания, где разъяснялся вопрос об автономии и принимались резолюции о желательности выделения марийских территорий в отдельную административную единицу. Таким образом, на этом этапе можно заметить определенное стремление дополнить проводимую «сверху» органами советской власти подготовительную работу своеобразной поддержкой «снизу». В итоге 4 ноября 1920 г. за подписями председателя Совнаркома В.И. Ленина и председателя ВЦИК М.И. Калинина был принят Декрет об образовании Автономной области марийского народа, которым предусматривалось образование Марийской автономной области в составе РСФСР. 25 ноября 1920 г. последовал Декрет «Об автономной области марийского народа». В состав области вошла территория площадью 18,66 тыс. кв. км. с населением численностью 338,5 тыс. человек, в том числе мари - 183 тыс. (54,1\%), русские -135 тыс. (40,5\%), татары - 19,5 тыс. (5,7 \%). Столицей области был утвержден город Краснококшайск, в 1927 г. переименованный в ЙошкарОла $[54$, с. 8].

В результате проведения политики продразверстки в Марийской АО к весне 1921 г. сложилась катастрофическая ситуация с продовольствием. Пораженное голодом население во многих местах начало громить продовольственные склады. В мае 1921 г. такие события, сопровождавшиеся человеческими жертвами, произошли в Кумужьяльской, Сернурской и Моркинской волостях, где разъяренные голодные жители захватили более пяти тысяч пудов хлеба из Госфонда. Прошло еще несколько дней - и разгром ссыпного пункта произошел в Ронге, вновь начались волнения в Сернуре, во время которых, по сообщению комитета РКП/б/, «крестьяне заявляют: если хлеба не дадите, мы вас задушим» [55]. Чтобы не произошло расправы с коммунистами, в Сернур и Ронгу были направлены вооруженные команды. Однако какого-то массового выступления, сколько-нибудь масштабного, не произошло. Отсутствие массовых вооруженных восстаний, наверное, можно связать с тем, что в годы гражданской войны территории, входившие в Марийскую АО, не были зоной военных действий. Кроме того, нужно сказать, что в Марийской области в тот период активно действовала Американская Администрация Помощи, значительная роль которой в спасении марийцев описана К. Сануковым.

Если говорить о дальнейшем развитии автономии, то происходила коренизация государственного и хозяйственного аппарата: марийцы вошли в органы управления, марийский язык стал использоваться в делопроизводстве, в деловой переписке, на собраниях, чего до этого никогда не было.

В дальнейшем, развитие автономии происходило по известному сценарию. В экономической сфрере большое значение получило строительство железной дороги, которой в Марийской АО не было до 1923 г. Значительные поступления в бюджет обеспечивала лесозаготовительная промышленность. В Марийской АО проводится политика, направленная на культурное и экономическое развитие народа мари, ликвидацию неграмотности. Образование, делопроизводство, собрания ведутся в том числе на марийском языке. Идет обсуждение вопроса о повышении статуса Марийской АО до автономной республики, спустя три года после получения статуса автономии происходит расширение территорий, за счет соседних Чувашской АО, Тарской АССР, Вятской и Нижегородской губерний. Уже к 1928 г. площадь Марийской АО увеличилась на 26\%, до 23,53 тыс.кв.км., а население по переписи 1926 г. составило 482,1 тыс. человек. Из общего числа населения 51,4\% - мари, 43,6\% - русские, 4,2\% - татары, 0,4 \% - чуваши и 0,4\% - прочие национальности. Марийцы проживали главным образом в трех южных кантонах, где 
они составляли 4/5 всего населения [56]. То есть как мы видим, по сравнению с 1920 г., временем создания автономной области, значительных перемен в этнической структуре населения не произошло. Несмотря на то, что титульный этнос составлял большинство населения, автономная область не стала автономной республикой, а даже, напротив, в 1928 г. вошла в состав Нижегородского края. Марийская АССР была провозглашена только в декабре 1936 г., когда говорить о какой-то реальной автономии не было смысла.

Завершая разговор об автономиях, мы рассмотрим Коми область. Революции 1917 г. вызвали всплеск национальных движений. Вслед за февральскими событиями появились идеи национального самоопределения коми народа, высказанные коми солдатами. Эти идеи были подхвачены в крае, и к 1918 г. получили вполне четкое оформление. Они активно обсуждались среди интеллигенции, а также на съездах советов. Уже в начале 1918 г. вопрос о создании национальной государственности коми народа был поставлен со всей определенностью. Приоритет в этом несомненно принадлежит Дмитрию Яковлевичу Попову, который 17 января того же года на Учредительном съезде выступил с предложением «установить автономию на совершенно свободных началах в порядке внутреннего управления...». В марте 1918 г. I съезд УстьСысольского Совета рабочих, солдатских и крестьянских депутатов послал в Архангельск телеграмму, в которой предлагалось «выделить в особую административную единицу зырян по этнографическим границам с правом законодательства, кроме армии, внешних сношений, монеты». По утверждению В.И.Чупрова, это был первый официальный документ по самоопределению коми народа. В 1918 г. при Наркомнаце был создан Зырянский отдел. Однако процесс создания или пока еще проектирования такой автономии был прерван гражданской войной. На территории Коми шли достаточно ожесточенные бои, так как белое движение имело широкую поддержку среди населения, крестьян. Этот фракт объясняется отчасти тем, что крестьяне здесь еще со времен крепостного права были государственными, не было такой ненависти к прежней государственной власти и соответственно к белому движению. Кроме того, нужно сказать, что иностранная интервенция в Архангельской губернии обеспечивала белых как оружием, так и материально.

В августе 1918 г. Архангельск был взят эсерами и кадетами при поддержке войск Антанты. Была учреждена так называемая Северная область. Армия Северной области насчитывала около 20 тыс. чел., также в Северной области находились силы союзников порядка 10 тыс. человек. В сентябре монархисты подняли путч в Архангельске, однако он был подавлен крестьянско-эсеровским ополчением при поддержке союзников. В период гражданской войны идет активное противостояние красных и белых, при активном участии иностранных войск, города и населенные пункты по нескольку раз переходили из рук в руки, например Ижем. Северная область просуществовала до февраля 1920 г., когда Красная Армия заняла Архангельск.

В том же 1920 г. возобновил свою деятельность зырянский отдел Наркомнаца. В 1920 г. его возглавил Д.А. Батиев, бывший эсер, сыгравший одну из ключевых ролей в создании государственности коми народа. При его непосредственном участии были подготовлены все необходимые документы, ставшие предметом обсуждения на первом всезырянском съезде коммунистов, состоявшемся в январе 1921 г. Выступивший на съезде с докладом Д.А. Батиев предложил создать государственность в форме автономной республики, включающей в себя территории коми-зырян и коми-пермяков, нижнюю Печору, Приполярную тундру и острова Ледовитого океана, а также ряд русских волостей соседних губерний. Съездом были избраны кандидаты в Областной Революционный Комитет (Обревком), на который возлагалась задача организации Коми АССР. Его председателем стал Д.И. Селиванов, заместителем - Д.А. Батиев. Был избран также Коми обком РКП(б) во главе с Я.Ф.Потаповым.

Неурожаи, трудовые повинности, инерция гражданской войны, привели к тому, что на территории Коми, как в других регионах, вспыхнули вооруженные выступления. Одно из них началось 18 мая 1921 г. в Усинском районе, готовились выступления в Ижме и Усть-Цильме, тогда же происходило восстание за Уралом, в Березовском уезде. Непосредственным поводом для них стали непомерно высокие поборы по продразверстке. Части особого назначения красных ликвидировали Усинское восстание в июне. В середине 1921 г. отряд Е.Кириллова, также пользовавшийся поддержкой местных жителей, предпринял попытку ликвидировать власть коммунистов на Пижме, но был разбит подоспевшими красноармейцами. Отдельные малочисленные группы белых в отдаленных районах уцелели и до более позднего времени. Небольшой отряд удорца Л.П. Маркова действовал, например, до 1925 г.

Процесс создания автономии тем не менее продолжался, 22 августа 1921 г. из восточных частей Архангельской и Северо-Двинской губерний РСФСР была образована автономная область Коми (Зырян). Ее административным центром стал Усть-Сысольск. В состав области вошли Усть-Сысольский уезд полностью, 21 волость с коми населением Яренского уезда, ИжмоПечорский уезд (большая часть Печорского уезда). В состав области вошла территория площа- 
дью 375 тыс. кв. км, с населением 179,847 тыс. чел. (по переписи 1920 г.), из них более $90 \%$ коми [57]. По административным границам следует добавить, что в 20-е гг. местные органы власти не раз возвращались к вопросу расширения автономии и созданию республики. Как пишет исследователь Жеребцов, по этому поводу происходили споры с Архангельской губернией, главным образов из-за территорий Печерского уезда и выхода к морю и по поводу территорий «Большой тундры» и ее административного подчинения [58]. Но к Коми были присоединены только Верхнепечорские волости Чердынского уезда Пермской губернии в 1923 г. [59]. Это не сказалось как-то существенно на этнической структуре населения: по переписи 1926 г., доля коми составляла $86,9 \%$ [60].

В языковом вопросе ситуация в Коми не отличалась от других национальных образований. ВЦИК 14 апреля 1924 г. принял Декрет «О мерах к переводу делопроизводства государственных органов в национальных областях и республиках на местные языки». В нем, в частности, предписывалось постепенно переводить делопроизводство на местные языки, при приеме на работу отдавать предпочтение лицам, владеющим местными языками, и т.д. Происходили внедрение коми языка в школьное образование, разработка письменности коми.

Что касается экономического развития, то нельзя не отметить, что руководители Коми добивались повышения статуса автономии, чтобы получить большую хозяйственную самостоятельность. С 1921 г. в Коми «пошли» финансовые и материальные ресурсы из центральных государственных органов, трестов «Северолес» и «Комилес», началось освоение месторождений полезных ископаемых, дорожное строительство, а также строительство жилья, школ, лечебных учреждений [61]. Нельзя не сказать, что были акционерные общества с иностранным капиталом «Руссанглолес» и «Руссголланлес». Казалось бы, Коми АО обладала огромными ресурсами для экономического развития, а подавляющая часть населения - это «титульная» нация. Тем не менее, статус АССР Коми получила только в 1936 г., в иную политическую эпоху. Возможно, дело было в отсутствии значительного процента русскоязычного населения, как это было в Чувашии. Очевидно, что процесс создания автономии в Коми по хронологии и механизму осуществления, условиям мало отличается от подобных процессов в Карелии с ее приграничным положением.

Разумеется, в статье рассмотрены не все автономии, созданные в рамках РСФСР, за что читатель может обвинить нас в манипуляции фактами и попыткой вместить в наши гипотетические построения только те из них, которые отвечают уже заданным целям исследования. С другой стороны, очевидны многие детали и общие черты в ходе решения территориальных, экономических, языковых вопросов. Кроме того, повсеместно можно наблюдать такую картину, когда вопреки логике построения автономий они как бы искусственно увеличиваются за счет присоединения "русских» районов из ближайших регионов. В целом можно сказать, что создание автономий, вне зависимости от их различий по географическому положению, национальному и религиозному составу населения, количеству сторонников и противников советской власти, внешнеполитическому воздействию, проходило по очень похожим сценариям и примерно в одно время. Напомним, создание автономий в 1919 г.: май - Башкирская; 1920 г.: май - Татарская, июнь - Карельская, июнь - Чувашская, ноябрь - Марийская, 1921 г.; август - Коми автономия. Остается только добавить, что в октябре 1918 г. создается Трудовая коммуна немцев Поволжья, выросшая в 1924 г. до АССР, в апреле 1921 г. - Бурят-Монгольская ОА (Восточной Сибири), в октябре 1921 г. - Крымская АССР, в январе 1922 г. - Карачаево-Черкесская АО и т.д. Как мы уже говорили, большевики придавали огромное значение решению национального вопроса еще задолго до 1917 г. Лидеры советского государства очень далеко и прагматично смотрят в будущее в плане этнической трансформации наций в мире в эпоху индустриализации и опасностей «федерализма» и слишком либерального решения национального вопроса, что могло закончиться «сепаратизмом» [62]. По иронии судьбы, именно автономии, которые не выросли до «союзных» республик, остались в составе РСФСР и России. Насколько процесс «автономизации» внутри РСФСР был направлен на решение национального вопроса в России или являлся одним из эпизодов борьбы за власть, сказать сложно. Но принцип взаимодействия с разными национальными движениями во многих случаях был идентичен. Национальные движения, активизировавшиеся после Февральской Революции, большевики стремились, где это возможно, сделать «советскими», привлечь лидеров из числа «националов», причем, как правило, чем сложнее было положение большевиков, тем меньше было требований к союзникам из числа «националов». От самостоятельных национальных лидеров, действительно создававших автономии, большевики стремились как можно скорее избавиться (от Валидова в Башкирии, от Султана Галлиева в Татарстане). Это во-первых. Во-вторых, процесс создания автономий, как мы уже видели, происходит в условиях гражданской войны и, как правило, сопряжен либо с наступлением Красной Армии, либо, напротив, активизацией белого движения. Для точной корреляции необходимы более подробные исследования. 
Третий момент, это сам территориально-национальный принцип создания автономий. На начальном этапе создается автономия в пользу титульного этноса. Но этот этнос оказывается не в абсолютном большинстве - при явной возможности создать эту автономию в границах традиционного расселения этноса с его преобладанием по численности над русским населением. Затем происходят территориальные изменения: как правило, в автономию включаются районы с русскоязычным населением. На втором этапе создается автономная республика, как в Карелии, либо расширяется территория (Марийская область, Башкирия), в результате такого фрормального повышения статуса или увеличения территории идет сокращение относительной численности титульного этноса, что, конечно, не отвечает принципу автономии и национального строительства. Причем там, где русского населения было значительно меньше (Коми, Марийская АО), автономные республики так и не были созданы (в Чувашии - только в 1925 г., после длительных дискуссий). То есть шаблоны и механизмы создания автономии были в общем едины и осуществлялись примерно одинаково, будь то Чувашия или Карелия.

Что касается внешнего фактора влияния, это, разумеется, было. Вопрос в том, где он был серьезнее и даже опаснее для большевиков: в Башкирии и Татарстане с населением в несколько миллионов человек, где само национальное движение было оформлено в виде военных национально-религиозных объединений с очень сильными и харизматичными лидерами или относительно мирной и малонаселенной Карелии? Возможно, что в этих случаях, как и во многих других, большевики демонстрировали международному сообществу миролюбивое решение национального вопроса в бывшей «тюрьме народов» как в приграничных территориях, так и на Урале, Поволжье и т.д.

Для нас важнее то, что очень схожие в общем и в частности процессы происходили в национальных регионах, иногда с разницей всего лишь в несколько месяцев. Вышеизложенное позволяет говорить, что «универсальность» подходов большевиков к национальному строительству даже на очень непохожих территориях диктовалась какой-то своей внутренней логикой, где декларированные и реальные цели не совсем совпадали, а тактика отвечала принципу «шаг вперед - два шага назад». Если говорить о Карельской автономии, то она была создана по тем же принципам и в силу тех причин, по которым создавались остальные автономные образования в РСФСР. Близость Финляндии, внешнеполитические аспекты, международное право и коммунистический интернационализм скорректировали этот процесс в пользу таких моментов, как: выбор финляндских коммунистов-иностранцев на роль лидеров карельской автономии, проведение всекарельского съезда и своего рода «референдума» по вопросу государственной принадлежности карельской нации. В остальном создание карельской автономии мало отличалось от создания автономий в других регионах.

\section{БИБЛИОГРАФИЧЕСКИЕ ССЫЛКИ}

1. Очерки Истории Карелии. Т. 2. - Петрозаводск: Карельское книжное изд-во, 1964. - 615 с

2. Левкоев А.А. Финляндская коммунистическая эмиграция и образование Карельской Автономии в составе РСФСР (1918-1923 гг.) // Общественно-политическая история Карелии 20 века. - Петрозаводск, 1995. - С. 24-50.

3. Килин, Ю. М. Карелия в политике советского государства, 1920-1941 гг. - Петрозаводск: Издательство ПетрГУ, 1999.- 275 c.

4. История Карелии с древнейших времен до наших дней / А. И. Афанасьева [и др.]; под общ. ред. Н. А. Кораблева. - Петрозаводск: Периодика, 2001. - 943 с.

5. Бутвило А. И. Карельская Трудовая Коммуна. - Петрозаводск: Издательство ПетрГУ, 2011. - 235 с.

6. Ленин В.И. Критические заметки по национальному вопросу. - Элиста: Калмыцкое книжное издательство, 1973. 247 с.; Сталин И. В. Марксизм и национальный вопрос // Подъем. - 1996.- N2.- С.117-144.

7. Машезерский В.И. Победа Великого Октября и образование советской автономной Карелии. - Петрозаводск: Карелия, 1978. - 138 с.

8. Юсила О., Хентиля С., Невакиви Ю. Политическая история Финляндии 1809-1995. - М.: Весь мир, 1998. - 384 c.

9. Очерки Истории Карелии. Т. 2. - Петрозаводск: Карельское книжное изд-во, 1964. - 615 с.

10. Бутвило А.И. Указ. соч. С. 42.

11. Соколов-Страхов К.И. Зимняя компания в Карелии 1921/22 г. (Борьба за обладание Мурманским незамерзающим портом и железнодорожными путями к нему). - Л.: Изд. Воен. тип. Упр. делами Наркомвоенмор и РВС CCCP, 1927. $-162 \mathrm{c}$

12. Там же. С. 45- 47 .

13. Килин Ю. М. Указ. соч. С. 56. ; Левкоев А. А. Указ. соч. С. 41

14. 14.Соколов-Страхов К. И. Указ. соч. С. 48.

15. Бутвило А.И. Указ. соч. С. 146.

16. Очерки истории Карелии. Т. 2. - Петрозаводск: Карельское книжное изд-во, 1964. - 615 с. Географические условия в Карелии не всегда располагали к такому административному делению. Следует отметить, что в КТК в апреле 1923 г. были переданы 5 поморских волостей из Онежского уезда Архангельской области и скорее всего решающим был географический фрактор.

17. Карелия в период восстановления народного хозяйства 1921-1925 / под ред. А.И. Афанасьевой, В. И. Машезерского. - Петрозаводск: Карелия, 1979. - 325 с. 
18. Такала И.Р. Национальное строительство или политический проект? Финский фрактор в становлении карельской автономии // Проникновение и применение дискурса национальности в России и СССР в конце XVIII - первой половине XX вв. : [сборник статей]. - Тарту, 2011. - С. 144.

19. История Карелии с древнейших времен до наших дней. -Петрозаводск: Издательство ПетрГУ, 2000.-645 c.

20. Килин Ю. М. Указ. соч. С. 86.

21. Такала И. Р. Указ. соч. С. 144.

22. http://www.idmedina.ru/books/school-book/?4130

23. Идель - одно из средневековых названий Волги

24. Территории, в которые входили части Уфимской, Пермской, Оренбургской и Самарской губерний, населённые башкирами.

25. История Башкортостана с древнейших времен до наших дней: в 2 т. / под ред. И.Г. Акманова, Т. 2. История Башкортостана. XX век. - Уфа: Китап, 2006. - 350 с.

26. Там же.

27. Там же.

28. Весьма схожая ситуация с КТК и её центром в г. Петрозаводск.

29. http://www.vatandash.ru/index.php?article $=405$

30. Роднов, М. И. Население Уфимской губернии по переписи 1920 гг. Этнический состав (Бирский, Златоустовский и другие уезды). - М.: ИЭА РАН, 2014. - 178 с.

31. По переписи 1897 г. население Мензлинского уезда: башкиры - 123736 чел., татары - 107025 чел., русские 107025 чел.

32. «Большая Башкирия» - второй проект создания автономной Башкирии 1917-18 гг., составленный Заки Валидовым. Предполагалось, что эта автономия будет включать в себя всю Уфимскую губернию, части и местности, населенные башкирами в Самарской, Пермской и Оренбургской губерниях.

33. Авангулов В.Г. Парламентаризм в Башкортостане: История и современность. -_Уфра: ГРИ «Башкортостан», 2005. - 304 с. Именно летом 1922 г. была упразднена Олонецкая губерния, а Петрозаводск стал столицей Карельской трудовой коммуны.

34. Согласно переписи население Бирского уезда: башкиры - 22,53\% 140928 чел., татары - 17,24\%-107 792 чел. славянское население - 26,23\%-165 734 чел., тептяри - 52000 чел., мишари - 51310 чел/ Роднов Указ. соч. С. 122.

35. Там же. С. 1364. Население Белебеевского уезда: башкиры - 53,78\% - 232960 чел., русские 20,40 \% - 88355 чел., татары -11,26\% - 48784 чел., чуваши 7,26\% - 31443 чел.

36. Там же. С. 14633

37. В 1926 г. общая численность населения Башкирской АССР составляла 2665836 чел., из них башкиры - 625845 чел, русские - 1064707 чел., татары - 461871 чел., мишари -135960 чел., тептяри - 23290 чел.

38. Башкортостан с древнейших времен до наших дней. В 2-х т. - Уфа: Китап, 2004., Т.2, С. 139 [Электроный реcypc] URL: http://historystudies.org/2012/07/landa-r-g-mirsaid-sultan-galiev/ (дата обращения: 29.03.2016) Выше мы говорили о том, что большевики в некоторой степени сами инициировали процесс создания ТатароБашкирской Республики, но это был март 1918 г., когда была другая военно-политическая ситуация.

39. Тасиров. И. Р. История государственности Татарстана. XX век. - Казань: Гасыр, 2005. - 384 с.

40. Татария в период НЭПа [Электронный ресурc]. URL:http://www.иске-казан.pфp/stati/49-tatariya-v-period-nepa (дата обращения: 29.03.2016)

41. http://edurt.ru/index.php?rubrika $=326 \&$ type $=1 \&$ lang $=1$

42. http://demoscope.ru/weekly/ssp/rus_nac_26.php?reg=536

43. Минеева Е. К. Создание национально-территориальной автономии народов мари, мордвы и чувашей // Известия Самарского научного центра РАН. - 2007. - Т. 9. - № 2. - С. 375

44. Нестеров В. А. Населенные пункты Чувашской АССР. 1917-1981 годы. - Чебоксары: Чуваш. кн. изд-во, 1981. $352 \mathrm{c}$.

45. Ратникова А.P. Волисполкомы и политическая ситуация в Чувашии в начале $20-x$ годов 20 века // Вестник Чувашского университета. - 2013. - № 2. - С. 29-32.

46. Орлов В.В. Этнополитическое и социально-экономическое развитие Чувашии в 20-годы XX века. Автореферат [Электронный ресурc] . URL: http://libweb.kpfu.ru/z3950/referat/090422_9.pdf (дата обращения 29.03.2016).

47. Там же.

48. Население Чувашской АССР по переписи на 1 января 1926: 915,3 тыс. чел., в т.ч. чуваши - 688,3 тыс. (75,2\%), русские - 176,9 тыс. (19,3\%), мордвы - 25,4 тыс. (2,8\%), татары - 24,0 тыс. $(2,6 \%)$ и др., только 5\% населения было городским. URL: http://enc.cap.ru/?Ink=148\&t=publ (дата обращения 29.03.2016)

49. http://demoscope.ru/weekly/ssp/rus_gub_97.php?reg=39

50. Этнос марийцы (мари) делятся на три группы: восточные мари, луговые и горные. Восточные мари отделились от луговых в XVI веке.

51. Марийская история в лицах [Электронный ресурc]. URL: http://marihistory.ru/index.php/2011-01-01-20-08-55/27192012-05-11-20-18-41 (дата обращения: 29.03.2016)

52. Минеева Е.К. Федеративное устройство Республики Советов и определение территориальных границ автономных образований в 20-30-е гг. на материалах мари, коми, чувашей // Вестник Чувашского университета. - 2007. Вып. 3. - С. 8.

53. Сануков К. Голод 1921-1922 годов в Марийской Автономной области и американская помощь [Электронный ресурc ]. URL: http://www.mariuver.info/rus/statja/ist/sanuk1.htm (дата обращения: 29.03.2016)

54. Автономная Марийская область [Электронный ресурc] URL:http://istmat.info/node/39989 (дата обращения: 29.03.2016)

55. По переписи населения Коми: коми - 93, 5 \%, русские - 6, 5\%, самоеды -1\%. Фаузер В.В., Е.Н. Рожкин, Г.В. Загайнова Республика Коми в XX веке: демография, расселение, миграция. Сыктывкар, 2001 г. URL: http://vvfauzer.ru/pub/mon/m_2001_1.pdf (дата обращения: 29.03.2016)

56. Жеребцов И.Л. Формирование внешних административных границ Коми Автономии в XX: материалы к научным чтениям памяти академика Ю.А. Полякова «Население России: историко-демографическое измерение» (Краснодар, 23-24 сентября 2014 г.) [Электронный ресурс] / И. Л. Жеребцов, Н. П. Безносова. - Сыктывкар: ИЯЛИ Коми НЦ УрО РАН, 2014. URL: http://illhkomisc.ru/wp-content/uploads/2014/11/zherebcov_beznosova_formirovanievneshnih-granic.pdf (дата обращения: 29.03.2016) 
57. По данным переписи населения на 1987 г. в Чердынском уезде проживало 105 тыс. человек. Фаузер В.В. Республика Коми в XX веке: демография, расселение, миграция [Электронный ресурс] / В. В. Фаузер, Е. Н. Рожкин, Г. В. Загайнова - Сыктывкар, 2001. URL: http://vvfauzer.ru/pub/mon/m_2001_1.pdf (дата обращения: 29.03.2016)

58. Трубин А.Н. Строительная отрасль Коми Края в первые десятилетия $\overline{X X}$ века (1901-1930) / Индустриализация Европейского Северо-Востока России: предпосылки, способы осуществления и влияние на социальноэкономическое развитие региона. Труды Института Языка, литературы и истории Коми НЦ УРО РАН вып 72. Сыктывкар 2013. C. 50-60, 282 c. URL: http://illhkomisc.ru/wp-content/uploads/2014/11/trudy-ijali_72.pdf (дата обращения: 29.03.2016)

59. Сталин И. «Национальный вопрос и марксизм» (1914 г.). В работе Сталина (авторство которой приписывают Бу харину), было отмечено, что излишний «федерализм» может привести к распаду Российской империи, а автономия позволит решить национальный вопрос и сохранить государство, которое независимо монархическое или демократическое, мыслилось в границах империи.

\section{REFERENCES}

1. Essays on the history of Karelia. T. 2. [Ocherki istorii Karelii. T. 2]. Petrozavodsk, 1964, pp. 615. (in Russ).

2. Levkoev A.A. Finnish Communist emigration and the formation of Karelian Autonomy with in the RSFSR (1918-1923 gg). [Finlyandskaya communisticheskaya emigratsiya I obrazovaniye Karelskoy Avtonomii v sostsve RSFSR (1918$1923 \mathrm{gg}$ ) ]. Obshchestvenno-politicheskaya istoriya Karelii 20 veka = Socio-political history of Karelia of the 20th century. Petrozavodsk, 1995, pp. 24-50. (in Russ).

3. Kilin Yu. M. Karelia in the politics of the Soviet state, 1920-1941 gg. [Karelia v politike sovetskogo gosudarstva, 19201941 gg.]. Petrozavodsk, 1999, pp. 275. (in Russ).

4. Afanasyeva A.I. The history of Karelia from ancient times to the present day. [Istoriya Karelii s drevneishih vremen do nashih dney]. Petrozavodsk, 2001, pp. 943. (in Russ).

5. Butvilo A.I. The Karelian Labor Commune. [Karelskaya Trudovaya Kommuna]. Petrozavodsk, 2011, pp. 235. (in Russ).

6. Lenin V.I. Critical remarks on the national question. [Kriticheskiye zametki po natsionalnomu voprosu]. Elista, 1973, pp. 247, Stalin I.V. Marxism and the national question. [Marksizm I natsionalnyy vopros]. Podyem = The rise. 1996. no 2. Pp. 117-144. (in Russ).

7. Mashezerskiy V.I. The victory of the Great October revolution and the formation of Autonomous Soviet Karelia. [Pobeda Velikogo Oktyabrya i obrazovaniye sovetskoy avtonomnoy Karelii]. Petrozavodsk, 1978, pp. 138 (in Russ).

8. Yusila O., Hentilya S., Nevakivi Yu. Political history of Finland 1809-1995. [Politicheskaya istoriya Finlyandii 1809-1995]. Moskva, 1998, pp. 384. (in Russ).

9. Essays on the history of Karelia. T. 2. [Ocherki istorii Karelii. T. 2]. Petrozavodsk, 1964, pp. 615. (in Russ).

10. Butvilo A.I. The Karelian Labor Commune. [Karelskaya Trudovaya Kommuna]. Petrozavodsk, 2011, pp. 42. (in Russ).

11. Sokolov-Strahov K.I. Winter campaign in Karelia 1921-1922 g. (The struggle for possession of ice-free Murmansk port and railway lines to it). [Zimnyaya kampaniya v Karelii 1921-1922 g. (Borba za obladaniye Murmanskim nezamerzayushchim portom i zheleznodorozhymi putyami k nemu)]. Leningrad, 1927, pp. 162. (in Russ).

12. Sokolov-Strahov K.I. Winter campaign in Karelia 1921-1922 g. (The struggle for possession of ice-free Murmansk port and railway lines to it). [Zimnyaya kampaniya $\vee$ Karelii 1921-1922 g. (Borba za obladaniye Murmanskim nezamerzayushchim portom i zheleznodorozhymi putyami k nemu)]. Leningrad, 1927, pp. 45-47. (in Russ).

13. Kilin Yu. M. Karelia in the politics of the Soviet state, 1920-1941 gg.. [Karelia v politike sovetskogo gosudarstva, 19201941 gg.]. Petrozavodsk, 1999, pp. 56. (in Russ); Levkoev A.A. Finnish Communist emigration and the formation of Karelian Autonomy with in the RSFSR (1918-1923 gg). [Finlyandskaya communisticheskaya emigratsiya I obrazovaniye Karelskoy Avtonomii v sostsve RSFSR (1918-1923 gg) ]. Obshchestvenno-politicheskaya istoriya Karelii 20 veka = Socio-political history of Karelia of the 20th century. Petrozavodsk, 1995, pp. 41. (in Russ).

14. Sokolov-Strahov K.I. Winter campaign in Karelia 1921-1922 g. (The struggle for possession of ice-free Murmansk port and railway lines to it). [Zimnyaya kampaniya v Karelii 1921-1922 g. (Borba za obladaniye Murmanskim nezamerzayushchim portom i zheleznodorozhymi putyami k nemu)]. Leningrad, 1927, pp. 48. (in Russ).

15. Butvilo A.I. The Karelian Labor Commune. [Karelskaya Trudovaya Kommuna]. Petrozavodsk, 2011, pp. 146. (in Russ).

16. Essays on the history of Karelia. T. 2. [Ocherki istorii Karelii. T. 2]. Petrozavodsk, 1964, pp. 615. (in Russ).

17. Afanasyeva A.I., Mashezerskiy V.I. Karelia in the period of recovery of the economy 1921-1925. [Kareliya v period vosstanovleniya narodnogo hozyaystva 1921-1925]. Petrozavodsk, 1979, pp. 325. (in Russ).

18. Takala I.R. National building or political project? The Finnish factor in formation of the Karelian autonomy. [Natsionalnoye stroitelstvo ili politicheskiy proyekt? Finskiy factor v stanovlenii karelskoy avtonomii]. Proniknoveniye i primeneniye diskursa natsionalnosti $v$ Rossii i SSSR v kontse XVIII- pervoy tpolovine XX vV. [The penetration and application of the discourse of nationality in Russia and the Soviet Union in the late XVIII - first half of XX centuries]. Tartu, 2011, pp. 144. (in Russ).

19. History of Karelia from ancient times to the present day. [Istoria Karelii s drevneishih vremen do nashih dney]. Petrozavodsk: Petrozavodsk, 2000, pp. 645

20. Kilin Yu. M. Karelia in the politics of the Soviet state, 1920-1941 gg. [Karelia v politike sovetskogo gosudarstva, 19201941 gg.]. Petrozavodsk, 1999, pp. 86. (in Russ).

21. Takala I.R. National building or political project? The Finnish factor in formation of the Karelian autonomy. [Natsionalnoye stroitelstvo ili politicheskiy proyekt? Finskiy factor $v$ stanovlenii karelskoy avtonomii]. Proniknoveniye i primeneniye diskursa natsionalnosti $v$ Rossii i SSSR $v$ kontse XVIII- pervoy tpolovine XX vv. [The penetration and application of the discourse of nationality in Russia and the Soviet Union in the late XVIII - first half of XX centuries]. Tartu, 2011, pp. 144. (in Russ).

22. Available at: http://www.idmedina.ru/books/school-book/?4130

23. Idel - one of the medieval names of the Volga.

24. Territory, which included part of Ufa, Perm, Orenburg and Samara provinces inhabited by the Bashkirs.

25. Akmanov I.G. The history of Bashkortostan from ancient times to the present day. [ Istoriya Bashkortostana s drevneyshih vremen do nashih dney]. Istoriya Bashkortostana. XX vek. [The History Of Bashkortostan. XX century]. Ufa, 2006, pp. 350. (in Russ).

26. Akmanov I.G. The history of Bashkortostan from ancient times to the present day. [ Istoriya Bashkortostana s drevneyshih vremen do nashih dney]. Istoriya Bashkortostana. XX vek. [The History of Bashkortostan. XX century]. Ufa, 2006, pp. 350. (in Russ). 
27. Akmanov I.G. The history of Bashkortostan from ancient times to the present day. [ Istoriya Bashkortostana s drevneyshih vremen do nashih dney]. Istoriya Bashkortostana. XX vek. [The History of Bashkortostan. XX century]. Ufa, 2006, pp. 350. (in Russ).

28. A very similar situation with Karelian autonomy and its center in Petrozavodsk.

29. Available at: $h t t p: / / w w w . v a t a n d a s h . r u / i n d e x . p h p ? a r t i c l e=405$

30. Rodnov M.I. The population of Ufa province according to the census $1920 \mathrm{gg}$. Ethnic composition (Birsk and Zlatoust and other counties). [Naseleniye Ufimskoy gubernii po perepisi $1920 \mathrm{gg}$. Etnicheskiy sostav (Birskiy, Zlatoustovskiy i drugiye uyezdy)]. Moskva, 2014, pp. 178. (in Russ).

31. According to the 1897 census, the population of the county Menzelinsky: Bashkirs - 123736 people, Tatars - 107025 people, Russian - 107025 people...

32. "Most of Bashkortostan" - the second project of creating an autonomous Bashkortostan 1917-18, compiled by Zaki Validov.. It was assumed that this autonomy will include all the Ufa province, and part of the area inhabited by the Bashkirs in Samara, Perm and Orenburg provinces.

33. Avangulov V.G. Parliamentarism in Bashkortostan: History and modernity. [Parlamentarizm v Bashkortostanye: Istoriya sovremennost]. Ufa, 2005, pp. 304. (in Russ).

34. Rodnov M.I. The population of Ufa province according to the census $1920 \mathrm{gg}$. Ethnic composition (Birsk and Zlatoust and other counties). [Naseleniye Ufimskoy gubernii po perepisi $1920 \mathrm{gg}$. Etnicheskiy sostav (Birskiy, Zlatoustovskiy i drugiye uyezdy)]. Moskva, 2014, pp. 122. (in Russ).

35. Rodnov M.I. The population of Ufa province according to the census $1920 \mathrm{gg}$. Ethnic composition (Birsk and Zlatoust and other counties). [Naseleniye Ufimskoy gubernii po perepisi $1920 \mathrm{gg}$. Etnicheskiy sostav (Birskiy, Zlatoustovskiy i drugiye uyezdy)]. Moskva, 2014, pp. 136. (in Russ).

36. Rodnov M.I. The population of Ufa province according to the census $1920 \mathrm{gg}$. Ethnic composition (Birsk and Zlatoust and other counties). [Naseleniye Ufimskoy gubernii po perepisi $1920 \mathrm{gg}$. Etnicheskiy sostav (Birskiy, Zlatoustovskiy i drugiye uyezdy)]. Moskva, 2014, pp. 146. (in Russ).

37. Earlier we talked about the fact that the Bolsheviks to some extent themselves have initiated the process of creating the Tatar-Bashkir Republic, but it was March 1918, when there was another military-political situation.

38. Bashkortostan from ancient times to the present day. [ Bashkortostana s drevneyshih vremen do nashih dney]. Ufa, 2004, T. 2, pp. 139. (in Russ). Available at: http://historystudies.org/2012/07/landa-r-g-mirsaid-sultan-galiev/ (accessed 29 March 2016).

39. Tagirov I.R. History of the statehood of the Republic of Tatarstan. XX century. [Istoriya gosudarstvennosti Tatarstana. XX vek]. Kazan, 2005, pp. 384. (in Russ).

40. Tatars in the period of NEP. [Tatariya v period NEPa]. Available at: URL:http://www.иске-казан.ppp/stati/49-tatariya-vperiod-nepa (accessed 29 March 2016).

41. Available at: http://edurt.ru/index.php?rubrika=326\&type $=1 \&$ lang $=1$

42. Available at: http://demoscope.ru/weekly/ssp/rus_nac_26.php?reg=536

43. Mineeva E.K. The creation of national-territorial autonomy of the peoples of the Mari, Mordovians and Chuvash. [Sozdaniye natsionalno-territorialnoy avtonomii mari, mordvy i chuvashey]. Izvestiya Samarskogo nauchnogo tsentra RAN = Proceedings of the Samara scientific center of RAS. 2007, T.9, no 2, pp. 375. (in Russ).

44. Nesterov V.A. The settlements of the Chuvash ASSR 1917-1981. [Naselennyye punkty Chuvashskoy ASSR 1917-1981 gg.]. Cheboksary, 1981, pp. 352. (in Russ).

45. Ratnikova A.R. Volispolkomov and political situation in the Chuvash Republic in the early 20-ies of the 20th century. [Volispolkomy i politicheskaya situatsiea v Chuvashii v nachale 20-h godov XX veka]. Vestnik Chuvashkogo universiteta= Bulletin of the Chuvash University. 2013, no 2, pp. 29-32. (in Russ).

46. Orlov V.V. Ethno-political and socio-economic development of Chuvash Republic in the 20 years of the twentieth century. [Etnopoliticheskoye I sotsialno-politicheskoye razvitiye Chuvashii v 20-ye gody XX veka]. Available at: http://libweb.kpfu.ru/z3950/referat/090422_9.pdf (accessed 29 March 2016).

47. Orlov V.V. Ethno-political and socio-economic development of Chuvash Republic in the 20 years of the twentieth century. [Etnopoliticheskoye I sotsialno-politicheskoye razvitiye Chuvashii v 20-ye gody XX veka]. Available at: http://libweb.kpfu.ru/z3950/referat/090422_9.pdf (accessed 29 March 2016).

48. Available at: $\mathrm{http}: / /$ enc.cap.ru/? Ink=148\&t=publ (accessed 29 March 2016).

49. Available at: http://demoscope.ru/weekly/ssp/rus_gub_97.php?reg=39

50. Ethnicity Mari (Mari) are divided into three groups: the Eastern Mari, meadow and mountains. Eastern Mari separated from the meadow in the XVI century.

51. Mari history in faces. [Mariyskaya istoriya $v$ litsah]. Available at: http://marihistory.ru/index.php/2011-01-01-20-0855/2719-2012-05-11-20-18-41 (accessed 29 March 2016).

52. Mineeva Ye.K. The Federal structure of the Soviet Republic and the definition of the territorial boundaries of the Autonomous formations in the 20-30s on the materials of the Mari, Komi, Chuvash. [Federativnoye ustroystvo Respubliki Sovetov i opredeleniye territorialnyh granits avtonomnyh obrazovaniy v 20-30-ye gg. na materialah mari, komi, chuvashey]. Vestnik Chuvashkogo universiteta= Bulletin of the Chuvash University. 2007, publication 3, pp. 8. (in Russ).

53. Sanukov K. The famine of 1921-1922 in the Mari Autonomous region and American help. [Golod 1921-1922 godov v Mariyskoy Avtonomnoy oblasti I amerikanskaya pomoshch]. Available at: http://www.mariuver.info/rus/statja/ist/sanuk1.htm (accessed 29 March 2016).

54. The Mari Autonomous oblast. [Avtonomnaya Maryskaya oblast]. Available at: http://istmat.info/node/39989 (accessed 29 March 2016).

55. Fauzer V.V., Rozhkin E.N., Zagaynova G.V. The Komi Republic in the twentieth century: demography, dispersal, migration. [Respublika Komi v XX veke: demografiya, rasseleniye, migratsiya]. Syktyvkar, 2001. Available at: http://vvfauzer.ru/pub/mon/m_2001_1.pdf (accessed 29 March 2016).

56. Zherebtsov I.L. The formation of the external administrative boundaries of the Komi Autonomy in the twentieth century: materials of scientific readings in memory of academician Yu. A. Polyakov, "The Population of Russia: historicaldemographic dimension" (Krasnodar, September 23-24, 2014). [ Formirovaniye vneshnih administrativnyh granits Komi Avtonomii $v$ XX veke: materialy $k$ nauchnym chteniyam pamyati akademika Yu. A. Polyakova "Naseleniye Rossii:istoriko-demograficheskoye izmereniye (Krasnodar, 23-24 sentyabrya 2014 goda)]. Available at: http://illhkomisc.ru/wp-content/uploads/2014/11/zherebcov_beznosova_formirovanie-vneshnih-granic.pdf (accessed 29 March 2016).

57. Fauzer V.V. The Komi Republic in the twentieth century: demography, dispersal, migration. [Respublika Komi $\vee$ XX veke: demografiya, rasseleniye, migratsiya]. Syktyvkar, 2001. Available at: http://vvfauzer.ru/pub/mon/m_2001_1.pdf (accessed 29 March 2016). 
58. Trubin A.N. The construction industry of the Komi Region in the first decades of the twentieth century (1901-1930). [Stroitelnaya otrasl Komi Kraya v pervyye desyatiletiya XX veka (1901-1930)]. Industrializatsiya Yevropeyskogo SeveroVostoka Rossii: predpossylki, sposoby osushchestvleniya $i$ vliyaniye na sotsialno-ekonomicheskoye razvitiye regiona. Trudy Instituta Yazyka, literatury I istorii Komi NTS URO RAN = The industrialization of the European North-East of Russia: prerequisites, means of implementation and impact on socio-economic development of the region. Proceedings of Institute of Language, literature and history of Komi science center URD RAS, publication 72. Syktyvkar, 2013, pp. 50-60, 282. (in Russ). Available at: http://illhkomisc.ru/wp-content/uploads/2014/11/trudy-ijali_72.pdf (accessed 29 March 2016).

59. I. Stalin, "The National Question and Marxism" (1914). In the work of Stalin (the authorship of which is attributed to Bukharin), it was noted that excessive "federalism" could lead to the disintegration of the Russian Empire and autonomy would solve the national question, and save the state which regardless monarchical or democratic, conceived within the boundaries of the empire.

\section{Информация об авторе}

Тебенко Вячеслав Александрович, соискатель, кафедра отечественной истории, Петрозаводский государственный университет, ООО «Сталь Сервис», г. Петрозаводск, Россия stal12h18n@mail.ru

Получена: 04.05.2016

Для цитирования статьи: Тебенко В.А. К вопросу о создании Карельской автономии 19201923 гг. Краснодар: Историческая и социально-образовательная мысль. 2016. Том 8. № 3. Часть 1. с Рp. 68-84 doi: 10.17748/2075-9908-2016-8-3/1-68-84

\section{Information about the author}

Vyacheslav A. Tebenko, Competitor, Department of Russian History, Petrozavodsk State University, Stal Service LTD,

Petrozavodsk, Russia stal12h18n@mail.ru

Received: 04.05.2016

For article citation: Tebenko V.A. To the question about creating the Karelian autonomy in 1920-1923. [K voprosu o sozdanii Karel'skoy avtonomii 1920-1923 gg.]. Krasnodar. Istoricheskaya i sotsial'no-obrazovatel'naya mysl'= Historical and Social Educational Ideas. 2016. Vol. 8. no. 3. Part. 1 Pp. $68-84$ doi: 10.17748/2075-9908-2016-8-3/1-68-84 